\title{
INFLAMMATION MEDIATORS IN EMPLOYEES IN CHRONIC EXPOSURE TO NEUROTOXICANTS
}

\section{GALINA MIKHAILOVNA BODIENKOVA, ROMAN ALEKSEEV, ELENA BOKLAZHENKO, and SVETLANA KURCHEVENKO}

\author{
Russian Academy of Medical Sciences, Angarsk, Russia \\ Siberian Department, Federal State Budget Institution "The East-Siberian Scientific Centre of Human Ecology" \\ Laboratory of Immunology
}

\begin{abstract}
Objectives: The aim of this work is to perform comparative estimation of cytokines levels in chlorinated hydrocarbons and metallic mercury exposure in employees in the dynamics of neurologic disorders formation. Material and Methods: The contents of cytokines IL-1 $\beta$, IL-2, IL-4, IL-6, TNF- $\alpha$, INF- $\gamma$ were determined in blood sera using the method of hardphasic immunoferment analysis. The significance of different average values was assessed using the parametric and non-parametric criteria Student (in normal distribution) and Mann-Whitney tests taking into account the Bonferonni correction (non-difference from normal distribution). Results: It was shown that, a number of inflammation mediators with the dominance, depending on the expositional toxicant and expression of neurological deficiency, take part in the neurointoxication development. Healthy employees show pro-inflammatory responses with different expression degree, which dominate in the immune regulation processes regardless of the expositional factors (metallic mercury vapors and chlorinated hydrocarbons). Conclusions: The production intensity and interconnection between the pro- and anti-inflammatory cytokines may change in the occupational injuries of the nervous system development process. The decrease in the serum concentrations of cytokines along with the increase of clinical manifestation severity may prove dysregulation of the immune system, which promotes maintaining of pathological process and progradient process of neurointoxication. The most obvious is the imbalance of cytokines in the employees exposed to metallic mercury (in all the examined groups) that increases neurointoxication in the distant period.
\end{abstract}

Key words:

Cytokines, Employees, Mercury, Chlorinated hydrocarbons, Neurointoxications

\section{INTRODUCTION}

Currently, production of vinyl chloride is necessary in many countries of the world. The employees exposed to a complex of chlorinated hydrocarbons are at risk of various effects: carcinogenic [1], mutagenic [2], embriogenic, teratogenic and other [3].

Recently, the investigations of some authors [4,5] have focused on the vinyl chloride influence on the nervous system. It should be noted that according to the sanitaryhygienic research of vinyl chloride production, the average levels of this chemical compound exceeded the hygienic norms 1.2-2 times from 1997 to 2000 (mean-shift maximum permissible concentration (MPC) $-5 \mathrm{mg} / \mathrm{m}^{3}$ ). The concentration of vinyl chloride was recorded at the level of 0.6-0.8 MPC from 2001-2004.

This work was financially supported by research work No. 021 "Study of formation mechanisms of nervous system disorders in exposure to production neurotoxicants of different chemical nature". Manager of the project: Galina Mikhailovna Bodienkova, PhD, Professor.

Received: December 2, 2013. Accepted: April 14, 2014.

Corresponding author: G.M. Bodienkova, Federal State Budget Institution “The East-Siberian Scientific Centre of Human Ecology" of Siberian Department of Russian Academy of Medical Sciences, Laboratory of Immunology, 665827, District 12a, house 3, Angarsk, Russia (e-mail: immun11@yandex.ru). 
In general, the problem of toxic damages to the nervous system caused by metallic mercury constitutes an actual problem of occupational medicine, professional pathology and human ecology. It is well known that mercury has cumulative features [6]. The most evident effect is the one it has in the cells of the control nervous system. In the case of production of caustics, for many years, the high levels of metallic mercury were recorded, exceeding super normal indices in the air of the workplace zone 5-10 times (meanshift MPC $-0.005 \mathrm{mg} / \mathrm{m}^{3}$ ).

Recently, researchers have paid great attention to the questions of neuro-immune interactions in different neurologic pathologies [7]. In the modern literature, the main question concerns the role of mediators of inflammation (pro- and anti-inflammatory cytokines) [8-10]. Cytokines net is a selfregulating system, the damage of which leads to excessive or insufficient synthesis of definite cytokines, which in turn may result in development of different pathologic processes constituting the basis of a wide range of human diseases. The proinflammatory cytokines may influence almost all organs and systems of the body, which take part in the regulation of the homeostasis system [11,12]. At the same time, the role of changes in the cytokine status in progradient process of neurointoxications forming, induced by occupation, is not studied well. There is still absence of the real methods for the diagnosis of professional neurotoxicosis.

The objective of this work is to perform a comparative estimation of cytokines levels with chlorinated hydrocarbons and metallic mercury in employees in the dynamics of neurologic disorders formation.

\section{MATERIAL AND METHODS}

One hundred ninety nine men were examined. Among them: 132 employees involved in the production of vinyl chloride and polyvinylchloride who are exposed to chlorinative hydrocarbons and 67 employees involved in the production of caustic who are exposed to metallic mercury vapors. The results of the advanced clinic functional examinations are based on the qualifying criteria of diseases and conditions according to the International Statistical Classification of Diseases and Related Health Problems 10th Revision (ICD-10).

The 1st group included 91 training employees without neuropsychological disorders with the working trainee period of $20.9 \pm 0.9$ years in the conditions of exposure to chlorinated hydrocarbons (mean age: $50.4 \pm 1.1$ years).

The 2nd group included 41 training employees involved in the same production process with the initial manifestations of intoxication with vinyl chloride, characterized by asthenic (emotionally-labile) disorder and vegetative dysfunction with peripheral vegetative disorders in the extremities and cardio-vascular diseases (working trainee period: $18.4 \pm 2.8$ years, age: $51.4 \pm 2.2$ years).

The 3rd group included 19 employees working under the influence mercury, seniority $-19.1 \pm 1$ years (mean age: $47 \pm 1.2$ years). The group is characterized by asthenic (emotionally-labile) disorders and vegetative dysfunction with peripheral vegetative disorders in the extremities and cardio-vascular diseases. In $34.7 \pm 5.8 \%$ of the cases from that group, the determined mercury level exceeded the normative indices in biological medium.

The 4th group consisted of 16 patients with occupational chronic mercuric intoxication (CMI) (working trainee period: $21.6 \pm 1.6$ years, mean age: $49.6 \pm 1.3$ years). The professional CMI was shown in I and I-II stages. Toxic encephalopathy was registered in $16.7 \pm 8.8 \%$ of the cases in patients with diagnosis of occupational CMI. The mercury content over normative indices was revealed in biological medium in $66.7 \pm 11.1 \%$ of the patients.

In the 5th group the 32 patients who were diagnosed with $\mathrm{CMI}$ in the postponed period, had been previously exposed to mercury (working trainee period: $15.6 \pm 0.8$ years, mean age: $53.3 \pm 0.8$ years). The toxic encephalopathy was revealed in $91.6 \pm 9.9 \%$ of the study group, cases with organic disorders of personality and cognitive dysfunction 
in $80.5 \pm 9.2 \%$ cases in patients with CMI in the postponed period. All the people who had worked with mercury were examined in 4 years repeatedly.

The control group consisted of 47 "practically healthy" men of the representative age and total working period, who were not occupationally exposed to any harmful substances.

The studies were performed after obtaining an informed consent from the patients and they corresponded to the ethic norms of Helsinki's Declaration (2000) and the Order of Public Health Ministry, RF No. 266 (19 June 2003). The contents of cytokines IL-1 $\beta$, IL-2, IL-4, IL-6, TNF- $\alpha$, INF- $\gamma$ were determined in blood sera using the method of hardphasic immunoferment analysis by means of the testsystems of the Company "VECTOR-BEST" (Novosibirsk). Statistical processing of the results was performed using the Packet of Applied Programs Statistica 6.0 in Windows (No. AXXR004E642326FA, Right Possessor of License is Federal State Budgetary Instutution "East-Siberian Scientific Centre of Human Ecology", Siberian Department of RAMS, Angarsk, Russia). Average arithmetical value (M), error of average arithmetical value (m), standard deviation $(\delta)$, median $(\mathrm{Me})$ and interquartile span (25th and 75 th percentiles) were calculated for the indices. The significance of different average values was assessed using the parametric and non-parametric criteria - Student (abnormal distribution) and Mann-Whitney tests taking into account the Bonferonni correction (no difference from normal distribution).

\section{RESULTS}

The results of the analysis of serum concentrations of the pro- and anti-inflammatory cytokines in the employees with a long-term working period and the persons with the initial manifestations of vinyl chloride neurointoxication are presented in Table 1. These data give evidence of the increased level of IL-1 $\beta$ in the working trainee employees without neuropsychiatric disturbances of $1.59 \pm 0.6 \mathrm{pg} / \mathrm{ml}$ and in the persons with initial manifestations of neurointoxication of $2.56 \pm 0.87 \mathrm{pg} / \mathrm{ml}$ compared to the control group $(1.15 \pm 0.4 \mathrm{pg} / \mathrm{ml} ; \mathrm{p}=0.004)$.

The compensatory increase of TNF- $\alpha$ both in the 1 st $(12.5 \pm 3.9 \mathrm{pg} / \mathrm{ml})$ and in the $2 \mathrm{nd}(16.7 \pm 3.9 \mathrm{pg} / \mathrm{ml}$ in the examined employees vs. $2.45 \pm 0.7$ in the control group; $\mathrm{p}=0.01)$ group should be noted. The most expressed tendency of IL-6 to increase in the examined persons in both groups $(7.59 \pm 3.0 \mathrm{pg} / \mathrm{ml}$ and $13.4 \pm 3.6 \mathrm{pg} / \mathrm{ml}$; in control $-1.68 \pm 0.4 \mathrm{pg} / \mathrm{ml}$ ) was also revealed. It should be noted that in the case of the initial manifestation of neurointoxication, IL-6 in the working trainee employees increases an analogous index about 2 - fold in comparison with the same employees without neuropsychiatric damages $(p=0.03)$.

As for studying changes in the serum concentration of pleiotropic IL-2, it is necessary to pay attention to its more expressed decrease in working-trainee employees with the initial manifestations of vinyl chloride intoxication $(2.06 \pm 1.02 \mathrm{pg} / \mathrm{ml})$ than in the employees without neuropsychiatric damages $(4.74 \pm 0.86 \mathrm{pg} / \mathrm{ml})$ and in the control group $(16.6 \pm 2.5 \mathrm{pg} / \mathrm{ml})$ respectively. Apartfrom the parallel increase of the production of pro-inflammatory cytokines in both groups of the examined individuals, a real decrease $(\mathrm{p}<0.05)$ of the anti-inflammatory IL-4 $-4.3 \pm 0.8 \mathrm{pg} / \mathrm{ml}$ in working trainee employees without neuropsychiatric damages and $5.2 \pm 1.5 \mathrm{pg} / \mathrm{ml}$ - with the initial signs of vinyl chloride intoxication (against $10.0 \pm 3 \mathrm{pg} / \mathrm{ml}$ in control) is observed.

The obtained results show increasing imbalance of cytokines in working trainee employees with the initial manifestation of vinyl chloride intoxication. This fact is proven by the comparative analysis of the cytokines in the examined individuals with the initial neurointoxication manifestation according to clinical and preclinical stages of the vegetative dysfunction syndrome (VDS). More expressed changes in persons with clinical a stage of VDS 
Table 1. Cytokine profile in employees exposed to chlorinated hydrocarbons

\begin{tabular}{|c|c|c|c|}
\hline Index & $\begin{array}{c}\text { I group - } \\
\text { employees without neuropsychiatric } \\
\text { disorders } \\
(\mathrm{N}=91) \\
\left(\mathrm{M} \pm \mathrm{m}, \mathrm{Me}\left(\mathrm{Q}_{25}-\mathrm{Q}_{75}\right)\right) \\
(\mathrm{pg} / \mathrm{ml})\end{array}$ & $\begin{array}{c}\text { II group - } \\
\text { employees with the initial manifestations of } \\
\text { intoxication by vinyl chloride } \\
(\mathrm{N}=41) \\
\left(\mathrm{M} \pm \mathrm{m}, \mathrm{Me}\left(\mathrm{Q}_{25}-\mathrm{Q}_{75}\right)\right) \\
(\mathrm{pg} / \mathrm{ml})\end{array}$ & $\begin{array}{c}\text { Control group } \\
(\mathrm{N}=47) \\
\left(\mathrm{M} \pm \mathrm{m}, \mathrm{Me}\left(\mathrm{Q}_{25}-\mathrm{Q}_{75}\right)\right) \\
(\mathrm{pg} / \mathrm{ml})\end{array}$ \\
\hline IL-1 $\beta$ & $\begin{array}{c}1.59 \pm 0.6^{\#} \\
0.1(0.0-0.1)\end{array}$ & $\begin{array}{c}2.56 \pm 0.87^{\#} \\
0.1(0.1-1.79)\end{array}$ & $\begin{array}{c}1.15 \pm 0.4 \\
0.01(0.01-1.17)\end{array}$ \\
\hline IL-2 & $\begin{array}{r}4.74 \pm 0.86^{\#} \\
1.0(0.2-4.6)\end{array}$ & $\begin{array}{c}2.06 \pm 1.02^{\# *} \\
0.32(0.14-0.56)\end{array}$ & $\begin{array}{c}16.6 \pm 2.5 \\
12.3(9.5-14.9)\end{array}$ \\
\hline IL-4 & $\begin{array}{c}4.3 \pm 0.80^{\#} \\
0.01(0.01-1.75)\end{array}$ & $\begin{array}{c}5.2 \pm 1.5^{\#} \\
0.09(0.01-1.8)\end{array}$ & $\begin{array}{c}10.0 \pm 3.0 \\
0.10(0.1-8.8)\end{array}$ \\
\hline IL-6 & $\begin{array}{c}7.59 \pm 3.0 \\
0.01(0.01-2.1)\end{array}$ & $\begin{array}{c}13.4 \pm 3.6^{*} \\
0.72(0.1-11.7)\end{array}$ & $\begin{array}{c}1.68 \pm 0.4 \\
1.0(0.01-2.5)\end{array}$ \\
\hline TNF- $\alpha$ & $\begin{array}{c}12.5 \pm 3.9^{\#} \\
0.01(0.01-4.97)\end{array}$ & $\begin{array}{c}16.7 \pm 3.9^{\#} \\
0.03(0.01-35.6)\end{array}$ & $\begin{array}{c}2.45 \pm 0.7 \\
0.89(0.12-2.4)\end{array}$ \\
\hline INF- $\gamma$ & $\begin{array}{c}4.1 \pm 0.8^{\#} \\
0.1(0.01-4.4)\end{array}$ & $\begin{array}{c}4.1 \pm 0.9 \\
0.11(0.09-6.5)\end{array}$ & $\begin{array}{c}4.79 \pm 2.3 \\
0.2(0.2-0.2)\end{array}$ \\
\hline
\end{tabular}

IL-1 $\beta$ - interleukin-1 $\beta$; IL-2 - interleukin-2; IL-4 - interleukin-4; IL-6 - interleukin-6; TNF- $\alpha$ - tumor necrosis factor $\alpha$; INF- $\gamma$ - interferon $\gamma$. $\mathrm{M}$ - mean; $\mathrm{m}$ - error of mean; $\mathrm{Me}$ - median; $\mathrm{Q}_{25}, \mathrm{Q}_{75}$ - quartile 25, 75 .

\# Relatively to control are significant, Mann-Whitney test, $\mathrm{p}<0.05$.

* Differences between groups.

were registered in working trainee employees without neuropsychiatric damages. Namely, lowering IL-2 down to $1.59 \pm 1.28 \mathrm{pg} / \mathrm{ml}(4.74 \pm 0.86 \mathrm{pg} / \mathrm{ml}$ in working trainee employees without the signs of neuropsychiatric damages) and increasing production of IL- 6 up to $7.59 \pm 3 \mathrm{pg} / \mathrm{ml}$ in working trainees without the signs of neuropsychiatric damages in comparison with $11.2 \pm 3.9 \mathrm{pg} / \mathrm{ml}$ in persons with a clinical stage of VDS.

The results of the prospective examination of the employees exposed to mercury (after 4 years) may confirm the increase in the immune failure in the employees with a long-term working period and with the initial manifestations of neurointoxication, in the patients with the revealed diagnosis of chronic mercury intoxication (CMI) and the persons with CMI in the postponed period (Table 2). When analyzing the results presented in Table 2, attention should be paid to the cytokine regulation disorder depending on the expression degree of pathological process.

The increase in the concentration of the inflammation initiators - IL-1 $1 \beta$ and TNF- $\alpha$ was revealed to occur in the employees exposed to mercury as compared to the control group in the 1 st examination. Therefore, the significant increase in the levels, namely IL-1 $\beta$ (up to $65.62 \pm 30.7 \mathrm{pg} / \mathrm{ml}$ vs. $1.15 \pm 0.36 \mathrm{pg} / \mathrm{ml}$ in the control subjects; $\mathrm{p}=0.0001$ ); IL-2 (up to $38.54 \pm 16.76 \mathrm{pg} / \mathrm{ml}$ vs. $16.6 \pm 2.5 \mathrm{pg} / \mathrm{ml}$ in the control subjects; $\mathrm{p}=0.0001$ ); TNF- $\alpha$ (up to $25.03 \pm 9.6 \mathrm{pg} / \mathrm{ml}$ vs. $2.45 \pm 0.7 \mathrm{pg} / \mathrm{ml}$ in the control subjects; $\mathrm{p}=0.000001$ ) and a clearly expressed trend of IL- 6 concentration in the serum to increase (up to $9.62 \pm 3.19 \mathrm{pg} / \mathrm{ml}$ vs. $1.68 \pm 0.35 \mathrm{pg} / \mathrm{ml}$ in the control subjects) was revealed in the employees with a longterm working period and with the initial manifestations of intoxication with mercury. The significant increase 


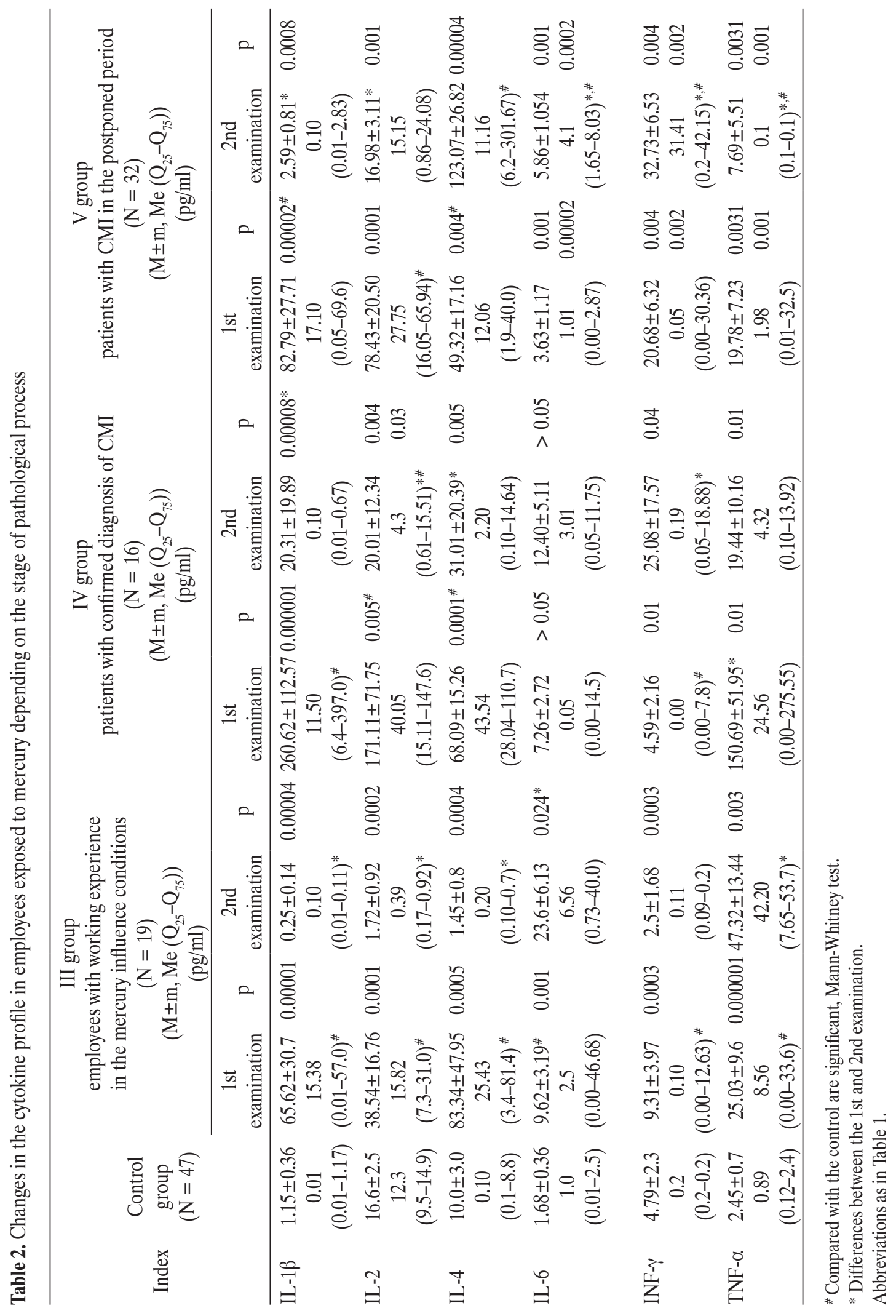


in the production of the anti-inflammatory IL-4 - up to $83.4 \pm 47.9 \mathrm{pg} / \mathrm{ml}$ as compared to the control subjects $(10.0 \pm 0.03 \mathrm{pg} / \mathrm{ml}, \mathrm{p}=0.0005)$ was also observed. The hyper production of IL-1 $\beta(260.62 \pm 112.5 \mathrm{pg} / \mathrm{ml})$, IL-2 $(171.11 \pm 71.75 \mathrm{pg} / \mathrm{ml})$ and TNF- $\alpha(150.69 \pm 51.95 \mathrm{pg} / \mathrm{ml})$ in the employees with a long-term working period with the initial manifestations of intoxication with mercury and in the patients with CMI should be of particular interest. The decrease in the cytokines was observed to occur in the patients with the increased severity of the pathological process in the postponed period of CMI, compared to the patients with CMI. The presented materials may confirm the increase in the changes in the cytokine system depending on the expression degree of the pathological process. The further follow-up of the same patients showed that aggravation of the alterations in the immune system in the employees with a long-term working period and with the initial manifestations of neurointoxication may occur in the same employees after 4 years. Namely, the decrease in the IL- $1 \beta(0.25 \pm 0.14 \mathrm{pg} / \mathrm{ml}, \mathrm{p}=0.00004)$, IL-2 $(1.72 \pm 0.92 \mathrm{pg} / \mathrm{ml}, \mathrm{p}=0.0002)$, IL-4 $(1.45 \pm 0.8 \mathrm{pg} / \mathrm{ml}$, $\mathrm{p}=0.0004)$ and the increase in the production of TNF- $\alpha$ $(47.32 \pm 13.44 \mathrm{pg} / \mathrm{ml}, \mathrm{p}=0.003)$, IL-6 $(23.6 \pm 6.13 \mathrm{pg} / \mathrm{ml}$, $\mathrm{p}=0.02$ ) were observed to occur in continuous exposure as compared to the 1st examination. The decrease in IL-1 $\beta$, IL-2, IL-4, TNF- $\alpha$ and the hyper production of INF- $\gamma$ (in contrast to the employees with a long-term working period with the initial manifestations of neurointoxication) was also observed in the patients with the diagnosis of CMI in dynamics comparing to the 1st examination. A sustained decrease in the concentration of IL-1 $\beta$, IL-2, TNF- $\alpha$ in the blood sera was observed in the patients with the postponed period of CMI (in the majority of examined persons).

The decrease in the level of TNF- $\alpha$ with the increase in severity of the pathological process may confirm the profound dysregulation of the immune system and may be one of the starting mechanisms of pro-gradient process of chronic mercury intoxication. Along with this, the secretion of INF- $\gamma$, the main marker of immune response (Th-1 type), was increased in the patients with CMI in continuous exposure to metallic mercury vapors, therefore, a more expressed alteration was observed in INF- $\gamma$ dynamics in the patients with CMI in the postponed period of neurointoxication.

The increase in the production of IL- 6 was revealed in all the groups in the dynamics of the pathological process development in the examination repeated after 4 years. As for anti-inflammatory IL-4, its significant decrease was observed in the group of the employees with a long-term working period with the initial manifestations of neurointoxication and in the patients with the diagnosis of CMI.

\section{DISCUSSION}

Studying the cytokines balance depending on the duration of exposure, the stage of the pathological process under exposure to metallic mercury vapors has allowed to reveal that the development of occupational lesions of the nervous system was followed by the dynamics alteration and correlation between the pro-inflammatory and antiinflammatory cytokines.

The results of the performed studies may expand and supplement available opinions on the role of cytokines in forming the adaptive and maladaptive responses in the development of occupational lesions of the nervous system. The comparative assessment of the changes in the cytokine content in the workers with a long-term working period with the absence of the disorders in the neuropsychical status and in the workers with a long-term seniority with the initial signs of neurointoxication has shown the more expressed change in the cytokine regulation under chronic exposure to metallic mercury vapors than under the influence of chlorinated hydrocarbons.

The increase in imbalance of the pro- and anti-inflammatory cytokines in dynamics (after 4 years) of the 
neurological disorders and in the development stage of the pathological process (the initial manifestations of intoxications, CMI, CMI in the postponed period of neurointoxication) was revealed. The common regularities and distinctive features in the cytokines content change in the blood sera of the employees were revealed depending on the stage of the pathological process.

The pro-inflammatory response trend may be considered as the common regularity at the initial stages of occupational neurointoxicosis resulting from the exposure to vinyl chloride and mercury. The cytokine imbalance was more expressed in the employees exposed to mercury (in all the examined groups), which may increase in the postponed period of neurointoxication. A number of mediators of inflammation with the prevalence depending on the expression stage of neurological disorders, the production of pro- and anti-inflammatory cytokines, may take part in the development of neurointoxications with vinyl chloride and metallic mercury vapors.

It should not be excluded that the chemical compounds may exert the direct immunotoxic effect on the immunocompetent cells, and therefore activate them and promote entering of the cytokines into the peripheral blood. This, in turn, may confirm the fact, that the activity of peripheral cytokines pool (not only available in the central nervous system) may confirm and pre-determine forming of a number of neurological disorders.

The hyperproduction of IL-1 $\beta$, IL-2, TNF- $\alpha$ at the early developmental stages of occupational neurointoxication may confirm association between the compensatory-adaptive mechanisms. The production intensity and the correlation between pro- and anti-inflammatory cytokines in exposure to metallic mercury vapors may be changed in the development process of the occupational lesions of the nervous system. The decrease in the serum concentrations of the cytokines with the increase in severity of clinical manifestations may confirm dysregulation of the immune system. This, in turn, may promote maintaining the pathological process and the progradient process of neurointoxication.

\section{REFERENCES}

1. Hsieh HI, Chen PC, Wong RH, Du CL, Chang YY, Wang JD, et al. Mortality from liver cancer and leukaemia among polyvinyl chloride workers in Taiwan: An updated study. Occup Environ Med. 2011;68(2):120-5, http://dx.doi. org/10.1136/oem.2010.056978.

2. Bolt HM. Vinyl chloride - A classical industrial toxicant of new interest. Crit Rev Toxicol. 2005;35(4):307-23, http:// dx.doi.org/10.1080/10408440490915975.

3. Sherman M. Vinyl chloride and the liver. J Hepatol. 2009;51(6):248-50, http://dx.doi.org/10.1016/j.jhep.2009. 09.012 .

4. Kalyaganov PI. [Clinical characteristics of the initial manifestations of chronic exposure to vinyl chloride]. Occup Med Industr Ecol. 2002;4:29-32. Russian.

5. Katamanova EV, Lakhman OL, Andreeva OK, Shevchenko OI. [To the question treatment and rehabilitation of patients with occupational neurointoxication]. Bull Cent Med Ecol. 2009;1(65):171-6. Russian.

6. Izmerov NF, editor. [Mercury]. Moscow: IRPTC, Centre for International Projects SSTC; 1996. Russian.

7. Kryzhanovskii GN, Magaeva SV, Makarov SV, Sepiashvili RI. [Neuroimmunopathology]. Moscow: Publishing Research Institute of Common Pathology and Pathophysiology RAMS; 2003. p. 282. Russian.

8. Rozhdestvenskii LM. [Cytokines and issues of urgent/early treatment of radiation human injuries]. Med Extreme Situations. 2007;1(19):46-53. Russian.

9. Glass CK, Saijo K. Nuclear receptor trans repression pathways that regulate inflammation in macrophages and T cells. Nat Rev Immunol. 2010;10(5):365-76, http:// dx.doi.org/10.1038/nri2748.

10. Di Rosa F. T-lymphocyte interaction with stromal, bone and hematopoietic cells in the bone marrow. Immunol. 
Cell Biol. 2009;87(1):20-9, http://dx.doi.org/10.1038/icb. 2008.84.

11. Bodienkova GM, Boklazhenko EV, Ivanova YV, Kurchevenko SI, Alekseev RY. [Role of cytokines in development of occupational neurointoxications in employees at different stages of pathological process]. Fundam Stud. 2010;11:22-6. Russian.

12. Demyanov AV, Kotov AY, Simbirtsev AS. [Diagnostical value of studying the levels of cytokines in clinical practice]. Cytokines Inflamm. 2003;3(2):20-33. Russian.

This work is available in Open Access model and licensed under a Creative Commons Attribution-NonCommercial 3.0 Poland License - http://creativecommons.org/ licenses/by-nc/3.0/pl/deed.en. 